\title{
Sampling in Management Studies of Public Organizations: Elite Orientation Model vs. Multiple Informants Model
}

\author{
Dimitris Karastathis ${ }^{1}$, Georgia Yfantidou ${ }^{2 *}$, Stella Kormikiari ${ }^{3}$, \\ Dimitris Gargalianos ${ }^{2}$, Antonia Kalafatzi ${ }^{4}$ \\ ${ }^{1}$ Department of Physical Education \& Sport Science, University of Athens, Athens, Greece \\ ${ }^{2}$ Department of Physical Education \& Sport Science, Democritus University of Thrace, Komotini, Greece \\ ${ }^{3}$ Department of Physical Education \& Sport Science, University of Thessaly, Volos, Greece \\ ${ }^{4}$ Faculty of Health Sciences \& Sport, University of Stirling, Scotland, United Kingdom
}

\begin{abstract}
The selection of the sample in a survey constitutes a significant parameter for the research process. A disagreement of opinions is observed in the field of management between researchers regarding which sample fabricates better results in surveys administered in public organizations. Some of them support that only the senior levels of the management hierarchy should participate in (Elite Orientation Model), while others support the participation of representatives from all levels (Multiple Informants Model). A questionnaire was administered to people from the three levels of Hellenic Sport Federations (HSFs) management hierarchy (employees, directors/managers, Board members) in order to investigate their perception about the degree to which excellence processes (enablers / results) were implemented. The purpose of this paper was to investigate which is the most appropriate model, regarding the selection of participants in studies about the administration /management of public organizations. Statistically significant differences regarding their perceptions for the topic under investigation were revealed, which were directly related to their level in the hierarchy. It was concluded that in similar studies the Multiple Informants Model fabricates more reliable results.
\end{abstract}

\section{Keywords:}

Federation; Sampling;

Elite Orientation Model;

Multiple Informants' Model;

Hierarchy; Public.

Article History:

Received: $\quad 04 \quad$ January 2021

Revised: $\quad 07$ March 2021

Accepted: 14 March 2021

Published: $01 \quad$ April 2021

\section{1- Introduction}

In different scientific fields many kinds of surveys have been implemented aiming at the collection of people's opinions belonging to particular groups. As the conclusions of these surveys are based upon the opinion of the participants their selection constitutes a very important parameter of the scientific process, hence they need to have proper characteristics (i.e., position in the organization, knowledge, experience, education, etc.). In the literature of the scientific field of management a disagreement of opinions is observed between researchers regarding the selection of the people that should participate in studies concerning an organization. There are researchers who suggest that only senior executives should participate in (Elite Orientation Model) [1-3], while others suggest participating of representatives from all managerial levels (Multiple Informants Model) [4-7].

At this point, it is crucial to clarify that during the last decades the academic community has been trying to define hierarchy concluding that its main elements are authority and responsibility [8-24]. These elements are used as a base

* CONTACT: Gifantid@phyed.duth.gr

DOI: http://dx.doi.org/10.28991/esj-2021-01272

(C) 2021 by the authors. Licensee ESJ, Italy. This is an open access article under the terms and conditions of the Creative Commons Attribution (CC-BY) license (https://creativecommons.org/licenses/by/4.0/). 
to create the levels of the hierarchy and delimit the scope of formal positions in the organization that corresponds to the people belonging to them [21, 25-27].

One of the challenges to organizational research is the need to rely on selected individuals, known as key informants, who participate in interviews or complete surveys to provide information about organizations as they are considered to be most familiar with the organization. Kim and Daniel (2020) examined individual characteristics of key informants and organizational characteristics associated with the discrepancy between the observations coming from two sources, they revealed that linking the two datasets should be used carefully with the consideration of key informants [28]. The findings of their study clearly showed that the characteristics of key informant matter to the reliability of data. As such, future organizational studies must control for key informant factors. It is important to make a comparison between the Elite Orientation Model and the Multiple Informants Model, in order to be provided evidence concerning which is the most appropriate for the selection of the people that should participate in studies in the field of administration / management of public organizations.

\section{2- Literature review}

In management studies the elite orientation of the sample is commonly used $[29,30]$. In such studies the respondents are selected from the higher levels of the organization on the grounds that they are more reliable because of the spherical knowledge they have about the entire organization [31-33], the participation of people from lower levels of the organization would produce less valid information [5] and they need less time, effort and possibly resources.

However, over the years this model received strong criticism [4-6] about the belief that only top executives in an organization should be interviewed in order to be proceeded the most valid information about the organization [34] on the grounds that studies addressed exclusively to them could be biased because the information will be provided will actually reflect top executives' work [35]. A study in an organization on the implementation of management by objectives tools [36] showed that the senior executives had a different perception for the topic under investigation and were far more optimistic than lower level executives. Another research that investigated the impact of Corporate Social Responsibility (CSR) on the working satisfaction and organizational commitment [37] concluded that the medium level executives presented lower tendency on social orientation than their subordinates.

Public management is never easy. Results are often hard to measure, public street-level employees have wide discretion and individual goals, and control and reward systems are frequently met with resistance or even hostility. Extant research in public management tells us that classical management tools can be effective. Public employees sometimes respond as intended to incentives, resulting in better performance and measurement and control systems can make public employees change their focus to reflect organizational goals. Training can have a strong effect on employee behavior and that training should be considered a powerful management tool [38].

Achieving organizational effectiveness under conditions of outcome ambiguity and information scarcity presents common challenges to public and nonprofit mangers. Additionally, outcome ambiguity combines with surplus nondistribution to produce another set of managerial challenges related to organizational efficiency. If outcomes are not systematically and accurately measured, then performance-based incentives are unlikely to be an effective means of improving efficiency. Similarly, if managers cannot personally profit from cost savings by retaining surpluses, then material incentives for improving efficiency are diminished [39].

Disagreements among executives in both public and private sector are not rare [40]. In public organizations various dimensions of employees' priorities in relation to senior executives were observed [5, 6, 41], while in private organizations extended disagreements between lower and higher administrators [34, 42], as well as among senior executives [43-45], have been recorded. A research that investigated the relationships between managers and politicians [46] showed that their interaction depends on the position they hold in the hierarchy and is mostly realized between political leaders and senior managers [2, 47].

The role of performance data on frontline employees' policy support was examined by Petersen (2020) [48]. The results revealed an imbalance in performance management systems. Caseworkers who were exposed to positive performance scores were more open to policy initiatives. One potential consequence may be that managers in organizations that perform well and thus produce positive performance results have an easier time implementing new policy initiatives compared to managers in average or poor performing organizations.

In contrast to the Elite Orientation Model, the Multiple Informants Model suggests that in relevant surveys representatives of all managerial levels should participate in order to be collected more accurate information [4]. The European Foundation for Quality Management (EFQM) Excellence Model (efqm.org) adheres to this model as it requires that representatives from the sector/unit that is being assessed participates in the evaluative team (divisional evaluation), and when the whole organization is assessed representatives from all managerial levels participate in the evaluation team [49]. Moreover, one of the biggest comparative studies in public management in Europe, titled "Coordinating for Cohesion in the Public Sector of the Future" (COCOPS), coordinated by a research consortium 
consisting of 11 universities from 10 countries, initially followed the Elite Orientation Model and the questionnaire that was constructed was addressed to senior executives and medium level employees. However, in order to be satisfied the social expediency issues, the study eventually included the lower level that was responsible for the services' provision as well.

\section{2-1-Importance of the Research}

Increasingly, organizations in Europe recognize that quality management is a way of managing their business, so that they gain profitability, efficiency and competitiveness while ensuring long-term success and meeting the needs of customers, employees, financial partners, all shareholders, but also the community at a whole.

In Greece, even though with a delay, quality management and assurance systems are implemented in some sectors and industry, mainly in manufacturing and production, in accordance to the guidelines of the Hellenic Standardization Organization (ELOT) [50].

Concerning sport, according to Smith and Stewart (1999) [51] “... the products and services coming from the commercial sector in general but also from government work are provided at unprecedented levels of quality. The adoption of quality management practices by the wider community further demonstrates that sports services are often below average." They also argue that if sports organizations and businesses do not adopt the doctrine of quality management and do not apply its tools, then their evolution will not be satisfactory.

The adoption of a Total Quality Management framework by Greek sports organizations, and in particular by state subsidies such as Hellenic Sport Federations, would ensure, in line with international as well as Greek examples of implementation in other areas, more efficient management, more efficient operation and higher level of service provision. It would also contribute to more objective financial subsidy, but also to its utilization by the subsidized body. It would therefore lead sports organizations overall to administrative excellence and consequently to excellent results. It is noted that despite the importance of the subject, there are no specific references in the domestic Greek sport literature for related or similar research, except for the research of Papadimitriou \& Taylor (2000) [52].

Consequently, there is a need to reflect the organizational - administrative profile of athletes according to a quality and excellence management framework, as the results obtained from the research can determine the organizational administrative level of HSFs in accordance to Total Quality Management. They can also be the starting point for adjustments and changes where necessary. Therefore, the above are also the main research questions of the present study that motivated it.

The purpose of the present paper was to compare the Elite Orientation Model and the Multiple Informants Model, in order to be provided evidence concerning which is the most appropriate for the selection of the people that should participate in studies in the field of administration / management of public organizations. The results of this paper followed a certain structure. Firstly, this paper examined the general differences in the perceptions among the three levels of managerial hierarchy. Also, the values in the Hotelling's T2 test for the opinions of the three levels of managerial hierarchy were tested. Moreover, the test of Homogeneity of Variance was used to reveal the variances among the comparison groups (three levels of managerial hierarchy). According to Homogeneity of Variance Test for the criteria, Fisher's statistical test and Welch's statistical test were used in mean values of the questions of the three levels of the managerial hierarchy for all criteria. Finally, the application of the Bonferroni control tested the mean values of the employees' answers in relation to the directors/managers and the members of the Board.

\section{3- Research Methodology}

\section{3-1-Research Questions}

1a. Are administrative excellence procedures in place and implemented in the administrative - organizational functions of the HSFs?

1b. What is the level of administrative excellence (examination of readiness to apply administrative excellence procedures) of HSFs regarding their administrative-organizational functions?

2. Are the basic principles of quality as described in the TQM?

3. Do the views of the 3 levels of the HSFs' administrative hierarchy (employees, directors / directors, board members) differ on the level of administrative excellence (investigating readiness to implement administrative excellence procedures) of HSFs on their administrative-organizational functions?

4. Do the opinions of HSFs on the level of administrative excellence (examination of readiness to apply administrative excellence procedures) regarding their administrative-organizational functions differ between:

(a) The so-called 'large', 'medium' and 'small' HSFs (number of employees, amount of budget, etc.); 
(b) Team and individual sports?

\section{3-2-Participants}

The sample of the study consisted of 100 employees of all three levels of the managerial hierarchy (48 employees, 15 directors/managers, 37 board members), who worked in 18 Hellenic Sport Federations (HSFs). According to the following statistical model their number is high:

Population size: $\mathrm{N}=50 \mathrm{HSFs}$

Sample size $\mathrm{n}$ for estimating $\mathrm{P}$ (percentage), with maximum error $\mathrm{d}$ :

$$
n \geq \frac{N\left(1+\frac{d^{2}}{z_{a / 2}^{2} \cdot p \cdot(1-p)}\right)}{1+\frac{N \cdot d^{2}}{z_{a / 2}^{2} \cdot p \cdot(1-p)}}
$$

$\mathrm{a}=0,05, \mathrm{~d}=0,10, \mathrm{p}=0,5, \mathrm{n}>7$

According to 2009 State Regular Financial Grants, 50 HSFs are recognized by the General Secretary of Sports and are responsible for the cultivation and development of the 31 Olympic and 19 non-Olympic sports.

\section{3-3-Measures}

The instrument used in this study was a questionnaire, which contained nine factors based on the EFQM Excellence Model and was validated in a previous study on the HSFs' management procedures under the scope of Total Quality Management (TQM) [53].

\section{3-4-Procedure}

HSFs are divided into 3 categories: 'Large', with a grant of over 1,000,000 $€(n=17,34 \%)$, 'Medium', with a grant of $100,000 €$ to $770,000 €(n=21,42 \%)$ and 'Small "with a grant of 10,000 to $75,000 €(n=12,24 \%)$. Because of the three sizes of HSFs to achieve statistical randomness in the sample selection, stratified random sampling was applied. Out of the $50 \mathrm{HSFs}$, and correspondingly to their total, $18 \mathrm{HSFs}$ were drawn by lot ('Large' $\mathrm{n}=7$ (34\%), 'Medium' $\mathrm{n}=$ $7(42 \%)$, 'Small' $n=4(24 \%)$. The researcher went in person to each of the 18 HSFs and distributed the questionnaires. Then, the respondents answered the questionnaires directly or after appointment and the researcher collect them back (Figure 1).

\section{3-5-Data Analyses}

The statistical analyses employed in this paper were the following: 1) descriptive statistical analysis in order to: a) obtain a general statistical overview regarding the perceptions of the people belonging to the three managerial levels in the HSFs hierarchy, b) examine their opinions regarding the degree to which processes of managerial excellence were implemented in their HSFs and c) ascertain whether there were any differences in their opinions in relation to their level in the managerial hierarchy, 2) MANOVA (Hotelling's $\mathrm{T}^{2}$ ) in order to determine whether the perception for the quality of the HSFs' organizational - managerial functions and the degree to which procedures of managerial excellence were implemented was different or not for the three levels of the hierarchy, 3) Homogeneity of Variance test and ANOVA (Fisher's statistical test and Welch's statistical test) in order to examine whether the differences in the three levels of managerial hierarchy were equal or not and 4) Bonferroni statistical test in order to investigate whether there were any significant statistical differences in the mean values of the lower level responses compared to the responses of the upper levels. 


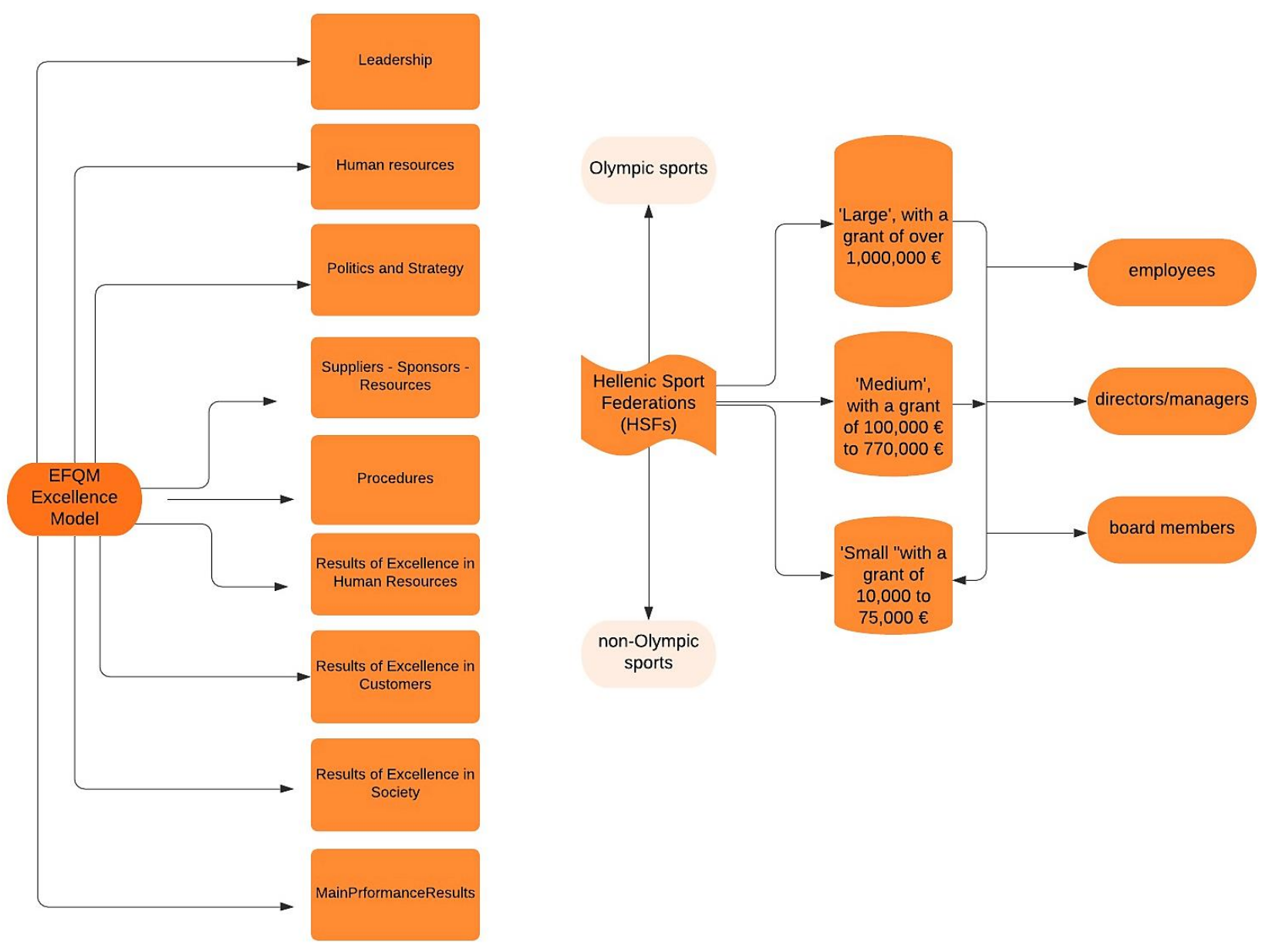

Figure 1. Flowchart of Methodology.

\section{4- Results}

General differences in the perceptions between the three levels of managerial hierarchy were recorded, with the employees expressing lower values than the directors'/managers, which were more in agreement with the ones of the board members (Table 1 and Figure 2).

Table 1. Descriptive statistics (level of position in the managerial hierarchy).

\begin{tabular}{|c|c|c|c|c|c|}
\hline ID & Exc & $\begin{array}{l}\mathrm{QM} \\
\text { nsions }\end{array}$ & $\mathbf{N}$ & Mean & Std. Deviation \\
\hline \multirow{4}{*}{1} & \multirow{4}{*}{ Leadership } & Employee & 48 & 2,47 & 1,139 \\
\hline & & Director-Manager & 15 & 3,81 & ,998 \\
\hline & & Board Member & 37 & 4,10 & ,635 \\
\hline & & Total & 100 & 3,46 & 1,227 \\
\hline \multirow{4}{*}{2} & \multirow{4}{*}{ Human resources } & Employee & 48 & 2,03 &, 810 \\
\hline & & Director-Manager & 15 & 3,30 & ,905 \\
\hline & & Board Member & 37 & 3,29 & ,882 \\
\hline & & Total & 100 & 2,87 & 1,055 \\
\hline \multirow{4}{*}{3} & \multirow{4}{*}{ Politics and Strategy } & Employee & 48 & 2,79 & ,983 \\
\hline & & Director-Manager & 15 & 3,61 & ,905 \\
\hline & & Board Member & 37 & 4,10 & 639 \\
\hline & & Total & 100 & 3,50 & 1,046 \\
\hline \multirow{4}{*}{4} & \multirow{4}{*}{$\begin{array}{c}\text { Suppliers - Sponsors - } \\
\text { Resources }\end{array}$} & Employee & 48 & 3,49 & ,923 \\
\hline & & Director-Manager & 15 & 3,96 & ,811 \\
\hline & & Board Member & 37 & 4,34 &, 770 \\
\hline & & Total & 100 & 3,93 & ,932 \\
\hline \multirow{4}{*}{5} & \multirow{4}{*}{ Procedures } & Employee & 48 & 2,53 & ,945 \\
\hline & & Director-Manager & 15 & 3,15 & ,666 \\
\hline & & Board Member & 37 & 3,42 & ,671 \\
\hline & & Total & 100 & 3,03 & ,908 \\
\hline \multirow{4}{*}{6} & \multirow{4}{*}{$\begin{array}{l}\text { Results of Excellence in } \\
\text { Human Resources }\end{array}$} & Employee & 48 & 1,84 & ,736 \\
\hline & & Director-Manager & 15 & 2,70 & ,679 \\
\hline & & Board Member & 37 & 2,81 & ,947 \\
\hline & & Total & 100 & 2,45 & ,933 \\
\hline
\end{tabular}




\begin{tabular}{|c|c|c|c|c|c|}
\hline \multirow{4}{*}{7} & \multirow{4}{*}{$\begin{array}{l}\text { Results of Excellence in } \\
\text { Customers }\end{array}$} & Employee & 48 & 2,05 & ,728 \\
\hline & & Director-Manager & 15 & 2,71 & ,720 \\
\hline & & Board Member & 37 & 3,30 & 1,101 \\
\hline & & Total & 100 & 2,69 & 1,048 \\
\hline \multirow{4}{*}{8} & \multirow{4}{*}{$\begin{array}{c}\text { Results of Excellence in } \\
\text { Society }\end{array}$} & Employee & 48 & 2,49 & 660 \\
\hline & & Director-Manager & 15 & 2,96 & 654 \\
\hline & & Board Member & 37 & 3,15 & ,607 \\
\hline & & Total & 100 & 2,87 & ,706 \\
\hline \multirow{4}{*}{9} & \multirow{4}{*}{ Main Performance Results } & Employee & 48 & 3,64 & ,687 \\
\hline & & Director-Manager & 15 & 4,31 & 371 \\
\hline & & Board Member & 37 & 4,51 & ,493 \\
\hline & & Total & 100 & 4,15 & ,710 \\
\hline
\end{tabular}

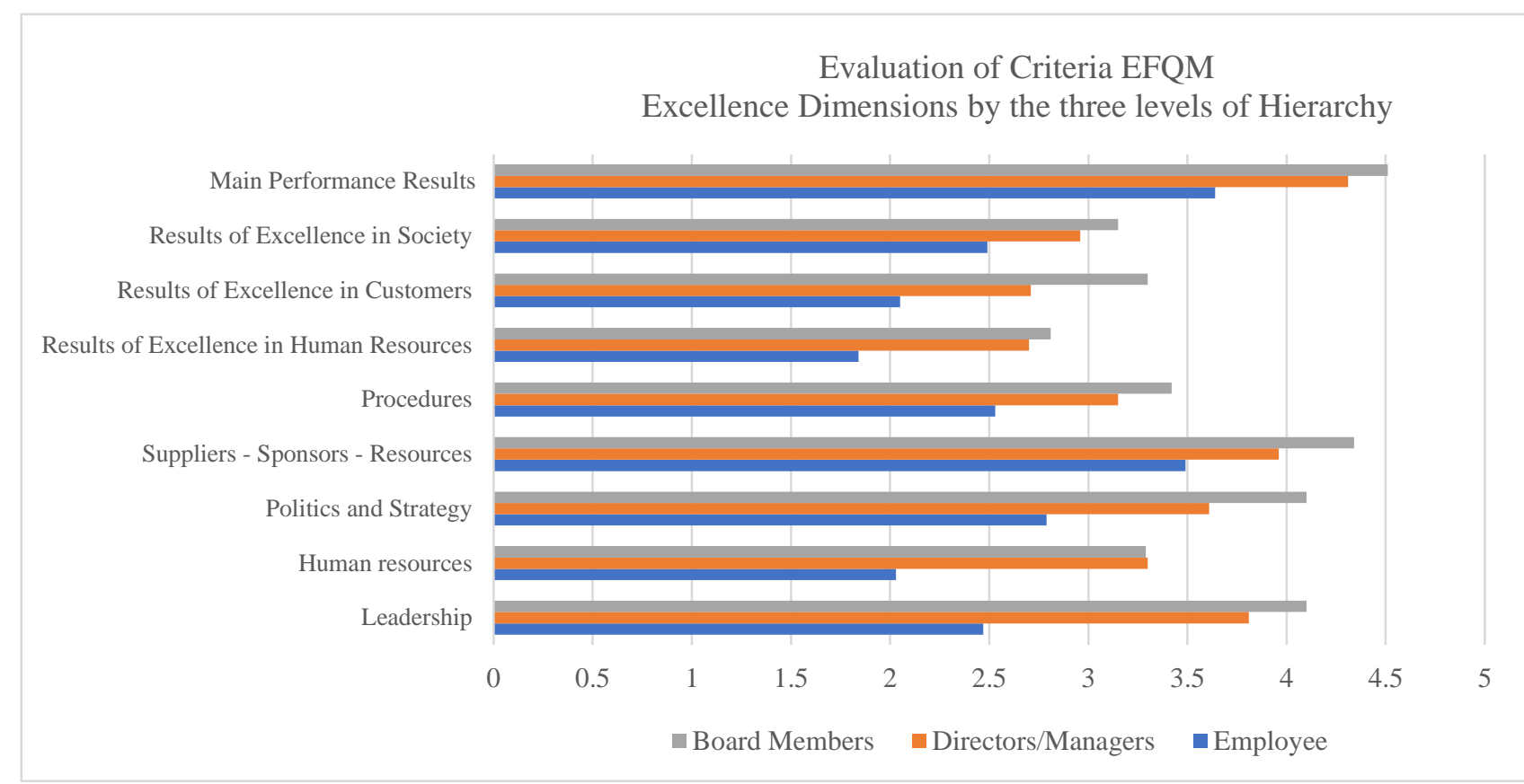

Figure 2. Evaluation of Criteria EFQM Excellence Dimensions by the three levels of Hierarchy.

The values in the Hotelling's T2 test were below 0,01 or 0,05 , meaning that there was a statistically significant difference in the opinions of the three levels of managerial hierarchy $(\mathrm{p}<0,01)$ (Table 2).

Table 2. Multivariable distribution analysis for the sample's opinions' comparison based on the hierarchical level of the participants.

\begin{tabular}{cccccc}
\hline Effect & Value & F & Hypothesis df & Error df & Sig. \\
\hline Level of Position Trace Hotelling's & 1,050 & 5,134 & 18,000 & 176,000 &, 000 \\
Hotelling's T $^{2}$ & 101,85 & 5,134 & 18,000 & 176,000 &, 000 \\
\hline
\end{tabular}

The test of Homogeneity of Variance revealed that the variances among the comparison groups (three levels of managerial hierarchy) were not equal (Table 3).

Table 3. Homogeneity of Variance test among the perceptions of the three levels of managerial hierarchy.

\begin{tabular}{lccccc}
\hline ID & $\begin{array}{c}\text { Criteria EFQM } \\
\text { Excellence Dimensions }\end{array}$ & Levene Statistic & df1 & df2 & Sig. \\
\hline 1 & Leadership & 9,643 & 2 & 97 &, 000 \\
2 & Human Resources &, 346 & 2 & 97 &, 708 \\
3 & Politics and Strategy & 7,951 & 2 & 97 &, 001 \\
4 & Suppliers - Sponsors - Resources &, 704 & 2 & 97 &, 497 \\
5 & Procedures & 4,660 & 2 & 97 &, 012 \\
6 & Results of Excellence in Human Resources & 1,781 & 2 & 97 &, 174 \\
7 & Results of Excellence in Customers & 3,532 & 2 & 97 &, 033 \\
8 & Results of Excellence in Society &, 715 & 2 & 97 &, 492 \\
9 & Main Performance Results & 5,717 & 2 & 97 &, 004 \\
\hline
\end{tabular}


According to Homogeneity of Variance Test for the criteria "Human Resources", "Suppliers - Sponsors Resources", "Results of Excellence in Human Resources" and "Results of Excellence in Society", Fisher's statistical test was used and it was observed that there were significant statistical differences in mean values of the questions of the three levels of the managerial hierarchy in all the criteria (Table 4).

Table 4. Analysis of Variance (Fisher's test).

\begin{tabular}{|c|c|c|c|c|c|c|c|}
\hline ID & $\begin{array}{r}\text { Criteria E } \\
\text { Excellence Di }\end{array}$ & $\begin{array}{l} \\
\text { ions }\end{array}$ & $\begin{array}{l}\text { Sum of } \\
\text { Squares }\end{array}$ & Df & $\begin{array}{c}\text { Mean } \\
\text { Square }\end{array}$ & $\mathbf{F}$ & Sig. \\
\hline \multirow{3}{*}{2} & \multirow{3}{*}{ Human Resources } & $\begin{array}{l}\text { Between } \\
\text { Groups }\end{array}$ & 39,989 & 2 & 19,995 & 27,594 & ,000 \\
\hline & & $\begin{array}{l}\text { Within } \\
\text { Groups }\end{array}$ & 70,286 & 97 & ,725 & & \\
\hline & & Total & 110,275 & 99 & & & \\
\hline \multirow{3}{*}{4} & \multirow{3}{*}{$\begin{array}{l}\text { Suppliers - Sponsors } \\
\text { - Resources }\end{array}$} & $\begin{array}{l}\text { Between } \\
\text { Groups }\end{array}$ & 15,402 & 2 & 7,701 & 10,587 &, 000 \\
\hline & & $\begin{array}{l}\text { Within } \\
\text { Groups }\end{array}$ & 70,553 & 97 & ,727 & & \\
\hline & & Total & 85,955 & 99 & & & \\
\hline \multirow{3}{*}{6} & \multirow{3}{*}{$\begin{array}{l}\text { Results of Excellence } \\
\text { in Human Resources }\end{array}$} & $\begin{array}{l}\text { Between } \\
\text { Groups }\end{array}$ & 21,970 & 2 & 10,985 & 16,604 & ,000 \\
\hline & & $\begin{array}{l}\text { Within } \\
\text { Groups }\end{array}$ & 64,173 & 97 & ,662 & & \\
\hline & & Total & 86,144 & 99 & & & \\
\hline \multirow{3}{*}{8} & \multirow{3}{*}{$\begin{array}{l}\text { Results of Excellence } \\
\text { in Society }\end{array}$} & $\begin{array}{l}\text { Between } \\
\text { Groups }\end{array}$ & 9,663 & 2 & 4,831 & 11,799 & ,000 \\
\hline & & $\begin{array}{l}\text { Within } \\
\text { Groups }\end{array}$ & 39,720 & 97 & ,409 & & \\
\hline & & Total & 49,383 & 99 & & & \\
\hline
\end{tabular}

According to Homogeneity of Variance Test, for the criteria "Leadership", "Politics and Strategy", "Procedures", "Results of Excellence in Customers" and "Main Performance Results", Welch's statistical test was used and it was observed that there were significant statistical differences in mean values of the questions of the three levels of the managerial hierarchy in all the criteria (Table 5).

Table 5. Analysis of Variance (Welch's test).

\begin{tabular}{ccccccc}
\hline ID & $\begin{array}{c}\text { Criteria EFQM } \\
\text { Excellence Dimensions }\end{array}$ & & Statist(a) & df1 & df2 & Sig. \\
\hline 1 & Leadership & Welch & 34,065 & 2 & 36,720 &, 000 \\
3 & Politics and Strategy & Welch & 27,159 & 2 & 37,540 &, 000 \\
5 & Procedures & Welch & 12,777 & 2 & 42,231 &, 000 \\
7 & Results of Excellence in Customers & Welch & 19,011 & 2 & 39,509 &, 000 \\
9 & Main Performance Results & Welch & 23,651 & 2 & 48,191 &, 000 \\
\hline
\end{tabular}

The application of the Bonferroni control revealed that there were statistically significant differences in the mean values of the employees' answers in relation to the directors/managers and the members of the Board on the criteria "Leadership", "Human Resources", "Politics and Strategy", "Procedures", "Results of Excellence in Human Resources", "Results of Excellence in Customers", "Results of Excellence in Society" and "Main Performance Results". In these criteria, the directors/managers and the members of the Board think that the degree to which excellence procedures are implemented is higher and that is the reason they "mark" it accordingly in comparison with the employees. Between the directors/managers and the members of the Board, a relevant agreement is ascertained in their perceptions with small differences (the members of the Board have a more positive opinion). The criterion "Suppliers Sponsors - Resources" indicated a statistically significant difference only between the members of the Board and the employees (Table 6). 
Table 6. Bonferroni statistical control for the levels of managerial hierarchy.

\begin{tabular}{|c|c|c|c|c|c|c|c|c|}
\hline ID & $\begin{array}{l}\text { Dependent } \\
\text { Variable }\end{array}$ & $\begin{array}{c}\text { Managerial } \\
\text { hierarchy (I) }\end{array}$ & $\begin{array}{c}\text { Managerial } \\
\text { hierarchy }(J)\end{array}$ & $\begin{array}{c}\text { Mean } \\
\text { Difference (I-J) }\end{array}$ & $\begin{array}{c}\text { Std. } \\
\text { Error }\end{array}$ & Sig. & $\begin{array}{l}95 \% \text { Conf. int. } \\
\text { Lower Bound }\end{array}$ & $\begin{array}{l}\text { Upper } \\
\text { Bound }\end{array}$ \\
\hline \multirow{6}{*}{1} & \multirow{6}{*}{ Leadership } & \multirow{2}{*}{ Employee } & Dir. / Man. & $-1,3250(*)$ &, 28405 & ,000 & $-2,0170$ &,- 6330 \\
\hline & & & Board & $-1,6175(*)$ & ,21008 &, 000 & $-2,1293$ & $-1,1057$ \\
\hline & & \multirow{2}{*}{ Dir. / Man. } & Employee & $1,3250(*)$ & ,28405 & ,000 & 6330 & 2,0170 \\
\hline & & & Board &,- 2925 & ,29394 & ,967 & $-1,0086$ &, 4236 \\
\hline & & \multirow{2}{*}{ Board } & Employee & $1,6175(*)$ & ,21008 &, 000 & 1,1057 & 2,1293 \\
\hline & & & Dir. / Man. & ,2925 & ,29394 & ,967 &,- 4236 & 1,0086 \\
\hline \multirow{6}{*}{2} & \multirow{6}{*}{ Human Resources } & \multirow{2}{*}{ Employee } & Dir. / Man. & $-1,2725(*)$ &, 25180 & ,000 & $-1,8859$ &,- 6590 \\
\hline & & & Board & $-1,2630(*)$ &, 18622 &, 000 & $-1,7167$ &,- 8093 \\
\hline & & \multirow{2}{*}{ Dir. / Man. } & Employee & $1,2725(*)$ &, 25180 & ,000 & 6590 & 1,8859 \\
\hline & & & Board & ,0095 & ,26056 & 1,000 &,- 6253 & ,6442 \\
\hline & & \multirow{2}{*}{ Board } & Employee & $1,2630(*)$ &, 18622 & ,000 & ,8093 & 1,7167 \\
\hline & & & Dir. / Man. &,- 0095 & ,26056 & 1,000 &,- 6442 &, 6253 \\
\hline \multirow{6}{*}{3} & \multirow{6}{*}{ Politics and Strategy } & \multirow{2}{*}{ Employee } & Dir. / Man. &,$- 8258(*)$ &, 25412 &, 005 & $-1,4449$ &,- 2067 \\
\hline & & & Board & $-1,3125(*)$ & ,18794 &, 000 & $-1,7704$ &,- 8546 \\
\hline & & \multirow{2}{*}{ Dir. / Man. } & Employee &, $8258(*)$ & ,25412 & ,005 & ,2067 & 1,4449 \\
\hline & & & Board &,- 4867 & ,26296 & ,202 & $-1,1273$ &, 1540 \\
\hline & & \multirow{2}{*}{ Board } & Employee & $1,3125(*)$ & ,18794 & ,000 & ,8546 & 1,7704 \\
\hline & & & Dir. / Man. &, 4867 & ,26296 & ,202 &,- 1540 & 1,1273 \\
\hline \multirow{6}{*}{4} & \multirow{6}{*}{$\begin{array}{l}\text { Suppliers - Sponsors } \\
\text { - Resources }\end{array}$} & Fmnloyee & Dir. / Man. &,- 4768 & ,25228 & ,185 & $-1,0914$ & ,1378 \\
\hline & & Employee & Board &,$- 8546(*)$ &, 18658 &, 000 & $-1,3092$ &,- 4001 \\
\hline & & & Employee & 4768 & ,25228 &, 185 &,- 1378 & 1,0914 \\
\hline & & Dir. / Man. & Board &,- 3779 & ,26105 &, 453 & $-1,0138$ &, 2581 \\
\hline & & & Employee &, $8546(*)$ & ,18658 & ,000 & ,4001 & 1,3092 \\
\hline & & Board & Dir. / Man. & ,3779 &, 26105 &, 453 &,- 2581 & 1,0138 \\
\hline & & & Dir. / Man. &,$- 6157(*)$ &, 24104 & ,037 & $-1,2030$ &,- 0285 \\
\hline & & Employee & Board &,$- 8910(*)$ &, 17827 & ,000 & $-1,3253$ &,- 4567 \\
\hline 5 & Procedures & Dir / Man & Employee &, $6157(*)$ & ,24104 & ,037 & ,0285 & 1,2030 \\
\hline 5 & Procedures & Dir. / Maan. & Board &,- 2753 &, 24942 &, 817 &,- 8829 &, 3324 \\
\hline & & Board & Employee &, $8910(*)$ &, 17827 & ,000 & ,4567 & 1,3253 \\
\hline & & Board & Director-Manager &, 2753 &, 24942 & 817 &,- 3324 & ,8829 \\
\hline & & Employen & Director-Manager &,$- 8560(*)$ & ,24060 & ,002 & $-1,4422$ &,- 2699 \\
\hline & & Employee & Board &,$- 9675(*)$ &, 17794 &, 000 & $-1,4010$ &,- 5340 \\
\hline 6 & Results of Excellence & Dir / Man & Employee &, $8560(*)$ &, 24060 & ,002 & ,2699 & 1,4422 \\
\hline & in Human Resources & Dir. / Man. & Board &,- 1115 & ,24897 & 1,000 &,- 7181 & ,4950 \\
\hline & & Board & Employee & ,9675(*) & ,17794 &, 000 &, 5340 & 1,4010 \\
\hline & & Board & Dir. / Man. &, 1115 & ,24897 & 1,000 &,- 4950 &, 7181 \\
\hline & & Fmployee & Director-Manager &,$- 6625(*)$ & ,26148 & ,039 & $-1,2995$ &,- 0255 \\
\hline & & Employee & Board & $-1,2532(*)$ & ,19338 &, 000 & $-1,7243$ &,- 7821 \\
\hline 7 & Results of Excellence & Dir / Man & Employee &, $6625(*)$ & ,26148 & ,039 & ,0255 & 1,2995 \\
\hline & in Customers & Dir. / Man. & Board &,- 5907 & ,27057 & ,094 & $-1,2499$ & ,0685 \\
\hline & & Board & Employee & $1,2532(*)$ & ,19338 & 000 & ,7821 & 1,7243 \\
\hline & & Board & Dir. / Man. & ,5907 & ,27057 & ,094 &,- 0685 & 1,2499 \\
\hline & & Employen & Director-Manager &,$- 4714(*)$ & , 18929 & ,043 &,- 9325 &,- 0102 \\
\hline & & Employee & Board &,$- 6650(*)$ & ,13999 &, 000 & $-1,0061$ &,- 3240 \\
\hline 8 & Results of Excellence & Dir / Man & Employee &, $4714(*)$ & ,18929 & ,043 & ,0102 & ,9325 \\
\hline & in Society & Dir. / Maan. & Board &,- 1937 & ,19587 & ,976 &,- 6709 &, 2835 \\
\hline & & Board & Employee &, $6650(*)$ & ,13999 & ,000 & ,3240 & 1,0061 \\
\hline & & Board & Dir. / Man. & ,1937 &, 19587 & ,976 &,- 2835 & ,6709 \\
\hline & & Emplowe & Director-Manager &,$- 6784(*)$ &, 17226 & ,000 & $-1,0980$ &,- 2587 \\
\hline & & Employee & Board &,$- 8699(*)$ &, 12740 &, 000 & $-1,1803$ &,- 5595 \\
\hline 0 & Main Performance & Dir /Man & Employee &, $6784(*)$ &, 17226 & ,000 & ,2587 & 1,0980 \\
\hline 9 & Results & Dir. / Man. & Board &,- 1915 & ,17826 &, 856 &,- 6258 &, 2428 \\
\hline & & & Employee & ,8699(*) &, 12740 & ,000 & ,5595 & 1,1803 \\
\hline & & Board & Dir. / Man. &, 1915 &, 17826 &, 856 &,- 2428 & ,6258 \\
\hline
\end{tabular}

\footnotetext{
* The mean difference is significant at the .05 level.
} 


\section{5- Discussion}

The way in which organizations respond to different demands has important consequences for their social legitimacy and access to critical resources, and in dealing with threats to their existence. As pointed out in the research of Pedras et al. (2020) [54], National Sport Federations have to deal with a complex array of tensions, challenges, and enablers which may require actions or compromises that favour one logic or another.

The results showed that there are significant statistical differences in the opinions of the three levels of the HSFs' managerial hierarchy regarding the extent to which processes of managerial excellence are implemented. More specifically, a statistically significant difference in the opinions of the three levels of the managerial hierarchy regarding the implementation of processes of managerial excellence was observed, which influences the quality of the HSFs' organizational - managerial functions. This also shows that the perception for the organization and management of the NSFs, which is represented by nine criteria - factors (13 in total, as there are also 4 sub-factors) is differentiated among the three levels of the managerial hierarchy.

More specifically, it was found that there are statistically significant differences among the three levels (except for the criterion "Suppliers - Sponsors - Resources", for which a statistically significant difference was found only between the Board members and the employees) in all the criteria. The highest degree for the implementation of excellence processes in the HSFs was expressed by the highest hierarchical level (Board members) in all cases, while the lowest degree was expressed by the lowest hierarchical level (employees). No agreement among them, in none of the criteria was observed. A main feature constitutes the criterion "Politics and Strategy", in which the employees' perception ranged at a non-systematic and deficient process implementation level $(2,79)$, the directors'/managers' one at a process implementation level which needs more effort in order to constitute a stable process $(3,61)$, and the same as the latter for the Board members (4,10). Similar results were found by Papadimitriou (2000) [52] for the HSFs' organizational effectiveness and by Fahlen (2010) [55] for the relationship between the individual's perceptions in relation to their hierarchical position, where it was found that the higher managerial levels had a more positive perception than the lower ones.

An explanation for this finding is that there is a high degree of commitment for the tasks that each level was responsible for. Table 2 presents the average of the answers in every criterion for all the three teams and in all criteria, where employees have the lowest averages, they are followed by the directors/managers, and the Board members are located on the top (only exception, the criterion "Human Resources", for which the averages between the directors/managers and the members of the Board are almost the same). This high differentiation rate regarding the answers of the three levels in all the criteria could be attributed to their way of thinking in relation to their level in the hierarchy.

While assessing these differences on the profit and loss basis, the Board members exhibit a more positive perception regarding the implementation of excellence parameters probably because they have the organizational and managerial responsibility and they are judged for the results of their work. In case that these results are not satisfying, then possibly their position is at risk, or questionable to say the least. The same, but in a smaller scale (possibly because of their lower responsibility position), stands also for the directors/managers: potential changes in the leadership could bring changes at their level of managerial hierarchy as well. On the other hand, the employees feel free to express their displeasure for a situation that exists in the organization. There is also a possibility that they desire changes in the managerial hierarchy in order to improve their situation financially, or hierarchically. Lee (2019) [56] added that leaders with high emotional intelligence can use more effective strategies to control themselves and manage their impulse emotions. This ability allows them to delay gratification for the benefit of their followers and to put followers' interests and needs above their own [56]. Further, leaders who can utilize their emotions to motivate others can quickly and accurately respond to the needs of their followers and motivate these followers in an individualized manner. Thus, these leaders show a great capacity to empower their followers and motivate them to work towards the goals of the organization [57].

\section{6- Conclusions}

Differences were found in their perceptions regarding the degree to which processes of managerial excellence are implemented (enablers/results), leading to the conclusion that the participation in the study of the HSFs' people from all managerial levels (employees, directors/managers, Board members) produces more reliable results. If only the higher managerial level had been selected to participate in (director/manager) or the highest one (Board member), then the results, and the deriving conclusions for that matter, would be different, in favor of these levels.

Specifically, the perceptions of the participants according to their level in the administrative hierarchy, as to whether or not the "conflicts between the departments of the Service" and whether or not, "the importance of information on the performance of public services" have increased. It is worth noticing that lower-ranking employees were more supportive than the other two levels (directors/managers and board members) at the perception that "the power of the Ministry of Finance has increased". The board members also argued to a lesser extent than the employees and directors/managers that "the conflict between the departments has increased". 
According to another view, the fiscal crisis is a window of opportunity to push for reform. However, a key question that needs to be answered, mainly from the point of view of the political system, is whether the changes that were promoted and implemented were real reforms. Furthermore, if these reforms aimed at improving the functioning of the public administration with a view to upgrading its service for citizens or were an inevitable consequence of violent fiscal adjustment.

\section{7- Declarations}

\section{7-1-Author Contributions}

All authors contributed to the design and implementation of the research, to the analysis of the results, and to the writing of the manuscript. All authors read and approved the final manuscript.

\section{7-2-Data Availability Statement}

The data presented in this study are available on request from the corresponding author.

\section{7-3-Ethical Approval}

Participants gave their written consent to use their anonymous data for statistical purposes. All of them were over 18 years old and voluntarily collaborated without receiving any financial compensation.

\section{7-4- Funding}

The authors received no financial support for the research, authorship, and/or publication of this article.

\section{7-5- Conflicts of Interest}

The author declares that there is no conflict of interests regarding the publication of this manuscript. In addition, the ethical issues, including plagiarism, informed consent, misconduct, data fabrication and/or falsification, double publication and/or submission, and redundancies have been completely observed by the authors.

\section{8- References}

[1] Derlien, Hans-Ulrich. "Repercussions of Government Change on the Career Civil Service in West Germany: The Cases of 1969 and 1982.” Governance 1, no. 1 (January 1988): 50-78. doi:10.1111/j.1468-0491.1988.tb00059.x.

[2] Mouritzen, P. E., and Svara, J. H. "Leadership at the apex: Politicians and administrators in western local governments." Pittsburgh: University of Pittsburgh Press, (2002).

[3]Trondal, Jarle. "An Emergent European Executive Order”, Oxford University Press (February 4, 2010). doi:10.1093/acprof:oso/9780199579426.001.0001.

[4] Enticott, G., G. A. Boyne, and R. M. Walker. "The Use of Multiple Informants in Public Administration Research: Data Aggregation Using Organizational Echelons." Journal of Public Administration Research and Theory 19, no. 2 (February 25, 2008): 229-253. doi:10.1093/jopart/mun017.

[5] Enticott, Gareth. "Multiple Voices of Modernization: Some Methodological Implications." Public Administration 82, no. 3 (August 2004): 743-756. doi:10.1111/j.0033-3298.2004.00417.x.

[6] Walker, R. M. "Using Multiple Informants in Public Administration: Revisiting the Managerial Values and Actions Debate." Journal of Public Administration Research and Theory 14, no. 3 (July 1, 2004): 417-434. doi:10.1093/jopart/muh022.

[7] Moyser, G., and Wagstaffe, M. "Research methods for elite studies.” London: Allen and Unwin, (1987).

[8] Adams, S. "Status Congruency as a Variable in Small Group Performance.” Social Forces 32, no. 1 (October 1, 1953): 16-22. doi:10.2307/2572852.

[9] Bales, R. F., Strodtbeck, F. L., Mills, T. M., and Roseborough, M. E. "Channels of communication in small groups.” American Sociological Review 16 (1951): 461-468. doi:10.2307/2088276.

[10] Benoit-Smullyan, Emile. "Status, Status Types, and Status Interrelations.” American Sociological Review 9, no. 2 (April 1944): 151. doi:10.2307/2086307.

[11] Bernstein, Irwin S. "Dominance: The Baby and the Bathwater.” Behavioral and Brain Sciences 4, no. 3 (September 1981): 419429. doi:10.1017/s0140525x00009614.

[12] Coie, John D., Kenneth A. Dodge, and Heide Coppotelli. "Dimensions and Types of Social Status: A Cross-Age Perspective." Developmental Psychology 18, no. 4 (July 1982): 557-570. doi:10.1037/0012-1649.18.4.557.

[13] Davis, Kingsley. “A Conceptual Analysis of Stratification.” American Sociological Review 7, no. 3 (June 1942 ): 309. doi:10.2307/2085360. 
[14] Goldhamer, Herbert, and Edward A. Shils. “Types of Power and Status.” American Journal of Sociology 45, no. 2 (September 1939): 171-182. doi:10.1086/218263.

[15] Gruenfeld, Deborah H., and Larissa Z. Tiedens. "Organizational Preferences and Their Consequences." Handbook of Social Psychology (June 30, 2010). doi:10.1002/9780470561119.socpsy002033.

[16] Lenski, Gerhard E. "Status Crystallization: A Non-Vertical Dimension of Social Status.” American Sociological Review 19, no. 4 (August 1954): 405-413. doi:10.2307/2087459.

[17] Lukes, Steven. "Power: A Radical View”, London: Macmillan (1974). doi:10.1007/978-1-349-02248-9.

[18] Magee, Joe C., and Adam D. Galinsky. "8 Social Hierarchy: The Self - Reinforcing Nature of Power and Status." Academy of Management Annals 2, no. 1 (January 2008): 351-398. doi:10.5465/19416520802211628.

[19] Ng, S. H. “The social psychology of power.” New York: Academic Press, (1980).

[20] Parsons, Talcott. "An Analytical Approach to the Theory of Social Stratification.” American Journal of Sociology 45, no. 6 (May 1940): 841-862. doi:10.1086/218489.

[21] Tannenbaum, Arnold S. "Control in Organizations: Individual Adjustment and Organizational Performance." Administrative Science Quarterly 7, no. 2 (September 1962): 236-257. doi:10.2307/2390857.

[22] Weber, M. "The theory of social and economic organization.” (A. M. Henderson and T. Parsons, Trans.). New York: Oxford, (1947).

[23] Nikolaidou, S., Yfantidou, G., Mavromatis, G., and Costa, G. "Evaluation of The Organizational Structure of Sports Organizations: The case of Greek MSO.” International Review of Services Management (IRSM) 1 no. 1 (2018): 1-22.

[24] Ellis, Frank. Peasant economics: Farm households in agrarian development. Vol. 23. Cambridge University Press, (1993).

[25] French, John R., Bertram Raven, and Dorwin Cartwright. "The bases of social power." Classics of Organization Theory 7 (1959): 311-320.

[26] Mills, C. W. “The power elite.” New York: Oxford University Press, (1956).

[27] Mintzberg, H. “The structuring of organizations.” Englewood Cliffs, NJ: Prentice-Hall, (1979).

[28] Kim, Mirae, and Jamie Levine Daniel. "Common Source Bias, Key Informants, and Survey-Administrative Linked Data for Nonprofit Management Research.” Public Performance \& Management Review 43, no. 1 (September 12, 2019): $232-256$. doi:10.1080/15309576.2019.1657915.

[29] Brudney, Jeffrey L., F. Ted Hebert, and Deil S. Wright. "Reinventing Government in the American States: Measuring and Explaining Administrative Reform.” Public Administration Review 59, no. 1 (January 1999): 19. doi:10.2307/977476.

[30] Meier, K. J., and L. J. O’toole. "Managerial Strategies and Behavior in Networks: A Model with Evidence from U.S. Public Education." Journal of Public Administration Research and Theory 11, no. 3 (July 1, 2001): 271-294. doi:10.1093/oxfordjournals.jpart.a003503.

[31] Cusumano, Michael A., and Akira Takeishi. "Supplier Relations and Management: A Survey of Japanese, Japanese-Transplant, and U.S. Auto Plants.” Strategic Management Journal 12, no. 8 (November 1991): 563-588. doi:10.1002/smj.4250120802.

[32] Hambrick, Donald C. "Strategic Awareness within Top Management Teams." Strategic Management Journal 2, no. 3 (July 1981): 263-279. doi:10.1002/smj.4250020305.

[33] Snow, Charles C., and Lawrence G. Hrebiniak. "Strategy, Distinctive Competence, and Organizational Performance." Administrative Science Quarterly 25, no. 2 (June 1980): 317. doi:10.2307/2392457.

[34] Phillips, Lynn W. "Assessing Measurement Error in Key Informant Reports: A Methodological Note on Organizational Analysis in Marketing.” Journal of Marketing Research 18, no. 4 (November 1981): 395-415. doi:10.2307/3151333.

[35] Purcell, John. "Best Practice and Best Fit: Chimera or Cul-de-Sac?” Human Resource Management Journal 9, no. 3 (July 1999): 26-41. doi:10.1111/j.1748-8583.1999.tb00201.x.

[36] Frazier, M. Andrew, and James E. Swiss. "Contrasting Views of Results-Based Management Tools from Different Organizational Levels.” International Public Management Journal 11, no. 2 (June 9, 2008): 214-234. doi:10.1080/10967490802095698.

[37] Marz, Joachim W., Thomas L. Powers, and Thomas Queisser. "Corporate and individual influences on managers' social orientation." Journal of Business Ethics 46, no. 1 (2003): 1-11. doi:10.1023/A:1024795705173.

[38] Jakobsen, Morten, Christian Bøtcher Jacobsen, and Søren Serritzlew. "Managing the Behavior of Public Frontline Employees through Change-Oriented Training: Evidence from a Randomized Field Experiment.” Journal of Public Administration Research and Theory 29, no. 4 (January 31, 2019): 556-571. doi:10.1093/jopart/muy080.

[39] Mitchell, George E., and Hans Peter Schmitz. "The Nexus of Public and Nonprofit Management." Public Performance \& Management Review 42, no. 1 (October 10, 2018): 11-33. doi:10.1080/15309576.2018.1489293. 
[40] Starbuck, W. H., and Mezias, J. M. “Opening pandora's box: Studying the accuracy of managers' perceptions.” Journal of Organizational Behavior 17 (1996): 99-117. doi:10.1002/(SICI)1099-1379(199603)17:2<99::AID-JOB743>3.0.CO;2-2.

[41] Guest, David E. "Human resource management - the workers' verdict." Human resource management journal 9, no. 3 (1999): 525. doi:10.1111/j.1748-8583.1999.tb00200.x.

[42] Hambrick, Donald C., and Phyllis A. Mason. "Upper Echelons: The Organization as a Reflection of Its Top Managers." The Academy of Management Review 9, no. 2 (April 1984): 193-206. doi:10.2307/258434.

[43] Bowman, Cliff, and Veronique Ambrosini. "Using Single Respondents in Strategy Research.” British Journal of Management 8, no. 2 (June 1997): 119-131. doi:10.1111/1467-8551.0045.

[44] Payne, R. L., and Pugh, D. “Organizational structure and climate.” In, M. Dunette, (Eds), Handbook of industrial and organizational psychology, Chicago, IL: Rand McNally, (1976): 1125-1173.

[45] Wooldridge, Bill, and Steven W. Floyd. "Research Notes and Communications Strategic Process Effects on Consensus." Strategic Management Journal 10, no. 3 (May 1989): 295-302. doi:10.1002/smj.4250100308.

[46] Jacobsen, Dag Ingvar. "The Relationship between Politics and Administration: The Importance of Contingency Factors, Formal Structure, Demography, and Time." Governance 19, no. 2 (April 2006): 303-323. doi:10.1111/j.1468-0491.2006.00316.x.

[47] Schedler, Kuno. "Politiker und Verwaltungsmanager in der Reform-Konflikt oder Symbiose? Eine Analyse anhand von Reformen in der Schweiz." dms-der moderne staat-Zeitschrift für Public Policy, Recht und Management 1, no. 1 (2008): 1920.

[48] Petersen, Niels Bjørn G. "Whoever Has Will Be Given More: The Effect of Performance Information on Frontline Employees' Support for Managerial Policy Initiatives.” Journal of Public Administration Research and Theory 30, no. 4 (March 4, 2020): 533-547. doi:10.1093/jopart/muaa008.

[49] McFarlane, D. G. "Managing Improvement in the Public Sector." Total Quality Management 12, no. 7 (December 1, 2001): 1047-1053. doi:10.1080/09544120120096224.

[50] Hellenic Republic, Law 2725/1999, Government Gazette, A-121/17-06-1999.

[51] Smith, A., and Stewart, B. "Sports Management: A Guide to Professional Practice.” Sydney: Allen and Unwin, (1999).

[52] Papadimitriou, Dimitra, and Peter Taylor. "Organisational Effectiveness of Hellenic National Sports Organisations: A Multiple Constituency Approach.” Sport Management Review 3, no. 1 (May 2000): 23-46. doi:10.1016/s1441-3523(00)70078-7.

[53] Karastathis, Dimitris, Yiannis Afthinos, Dimitris Gargalianos, and Nicholas D. Theodorakis. "The EFQM Excellence Model: An Exploratory Attempt for Assessing the Hellenic National Sport Federations.” International Journal of Sport Management, Recreation and Tourism 14 (August 25, 2014): 38-67. doi:10.5199/ijsmart-1791-874x-14c.

[54] Pedras, Loïc, Tracy Taylor, and Stephen Frawley. "Responses to Multi-Level Institutional Complexity in a National Sport Federation.” Sport Management Review 23, no. 3 (June 2020): 482-497. doi:10.1016/j.smr.2019.05.001.

[55] Fahlén, Josef. "Clashing interests-local sport policy through interorganizational networks." In 7th European Sport Sociology Congress. Porto, Portugal, May 5-8, 2010. University of Porto, Faculty of Sport, (2010).

[56] Lee, Ye Hoon. "Emotional Intelligence, Servant Leadership, and Development Goal Orientation in Athletic Directors." Sport Management Review 22, no. 3 (June 2019): 395-406. doi:10.1016/j.smr.2018.05.003.

[57] Barling, Julian, Frank Slater, and E. Kevin Kelloway. "Transformational Leadership and Emotional Intelligence: An Exploratory Study.” Leadership \& Organization Development Journal 21, no. 3 (May 2000): 157-161. doi:10.1108/01437730010325040. 